Copyright (C) 2019 by Academic Publishing House Researcher

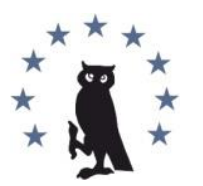

Published in the Russian Federation

European Researcher. Series A

Has been issued since 2010.

E-ISSN 2224-0136

2019, 10(3): 156-162

DOI: $10.13187 / \mathrm{er} .2019 \cdot 3.156$

www.erjournal.ru

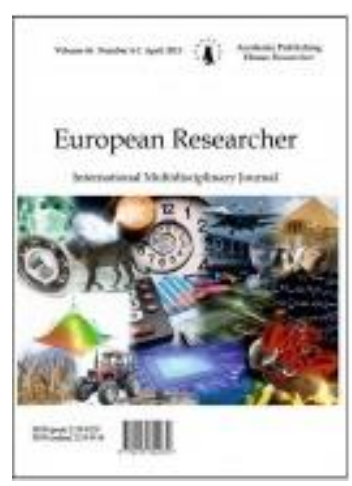

\title{
Syria Policy of Russia as a Permanent Member of the United Nations Security Council ${ }^{*}$
}

\author{
Meryem Gulnar a, Filiz Katman a , * \\ ${ }^{a}$ Istanbul Aydın University, Turkey
}

\begin{abstract}
This paper investigates the historical roots, cooperation and interests of Russia and Syria and their reflections to the world. In this paper, relations between Russia and Syria are considered as the period after the establishment of both the Soviet Union period and the Russian Federation. Relations between Russia and Syria have started to develop successfully since the early days of the USSR. Topics discussed in the thesis are the beginning of the Egyptian and Tunisian uprisings called the Arab Spring and the rise of this uprising to Syria in 2011. In addition the policies of the United Nations about these uprisings and the policies of Russia as the permanent member of the Security Council are presented. The main argument of this paper is that the main reasons of the Syrian crisis that reverberate all over the world, the source of the power of Assad, the role of Russia in the region and the interests cannot be ignored. Moreover, paper tries to explain these issues by shedding light from the theoretical window presented by realism. After the disintegration of the USSR, the traces of chaos and frustration experienced by Russia were largely erased during the period of Vladimir Putin. In the period of Putin, Russia's trade increased with increasing oil and gas revenues; living standard of the people has risen. Russia's growing economic power has drawn new horizons for foreign policy and Russia has pursued foreign policy based on power. The main reason for his support for the Assad regime is both economic and political; it tries to protect the region's power especially against the West. At the same time, with the Syrian Crisis of 2015, Russia has now shown that it can intervene as a global power in matters of its own interest not only in its own region, but in any part of the world.
\end{abstract}

Keywords: realism, Russia, Syria, United Nations, United Nations Security Council.

\section{Introduction}

Syria has an old and critical position where various civilizations and cultures pass through their lands and many invasions and events occur. Syria is a long history and culture as well as the current situation is also very interesting and has attracted the attention of the whole world. The academic analysis of the relations between Syria and Russia is one of the important subjects for the scholars who are interested in the political dynamics in the Middle East and specifically in Syria. The cultural and political legacy of Syria in the region is very important. Thus, it has always played an important role in the Middle East especially with regard to long relations with Russia.

\footnotetext{
${ }^{*}$ This article is based on the dissertation of the author entitled Meryem Gulnar, Syria Policy of Russia as Permanent Member of The UN Security Council

${ }^{*}$ Corresponding author

E-mail addresses: filizkatman@aydin.edu.tr (F. Katman), meryemgulnar@gmail.com (M. Gulnar)
} 
The most painful leg of the Arab Spring was Syria. Long-standing riots in Syria have turned into a civil war due to political polarization. The devastating effects of war led to one of the greatest human tragedies in history in the country. Millions of people have fled the country or have been displaced. The situation of immigrants who escaped from the crisis of Syria took the attention of lots of people in the world. Entire world is curious about what will happen to the civil war in Syria. The main objective of this study is to investigate the interests of a permanent member of the United Nations Security Council (UNSC), Russia in Syria. Why Syria is important for Russia and Russian interests in Syria are other questions to be investigated in the study.

\section{Russia-Syria Relations in the Pre-Cold War Era}

After World War II, the Middle East has an important geopolitical, geostrategic and geoeconomic area. For the US and the Soviet Union. For this reason, both states have taken the necessary steps to establish influence in the region. For example, in 1944, despite the opposition of France, the Soviet Union and the US recognized Lebanon and Syria as unconditionally sovereign states.Following these developments, France had to accept to withdraw its troops from the Syrian territory and the French mandate, which continued for 25 years in Syria, ended on 17 April 1946.

During this period, the tension in Suez caused the Syrian administration closer to Soviet Russia. Moreover Syrian Defense Minister Halit al-Azm visited the Soviet Union on 24 July-7 August 1957 and made a series of meetings. As a result of these interviews, the signing of some agreements between the parties has shown that the burgeoning relations have reached a great stage as of 1954, because according to these agreements; The Soviet Union would provide \$500 million of economic and military aid to Syria, which would be used for the construction of a new port in Latakia, the sale of arms, the financing of irrigation and energy projects in Syria, and the construction of highways, railways and airports. (Karabulut, 2007: 74).

In this period of Syria, which is called the Traditional Ba'ath Phase (1963-1966), it is observed that Syria has the chance in to build intimate relations with the Soviet Union and the Iron Curtain states. Although Syrian foreign policy actors have always stated that they have adopted the principle of neutrality in foreign policy conduct in the Ba'ath Regulation, but they chose to stand closer to the Eastern Bloc countries than the Western bloc, both ideologically and politically.

In the period of Neo-Baath (1966-1970), the Soviet Union followed a strategy to silently follow the policies of the new political formation in Syria. Then a delegation from the Soviet Union visited Syria on March 24, 1966, and a delegation from Syria visited the Soviet Union on 18 April 1966. As a result of the interviews, the authorities of the two countries decided to develop cooperation in political, cultural, economic and military fields based on norms of mutual equality, non-interference in domestic affairs and respect for sovereign rights. After this agreement, many Soviet experts came to Syria to provide assistance in the field of education and economic and military aid continued. Syria, in the period between 1954-1970, over 580 million dollars from the Eastern Bloc military; Around 440 million dollars were also the seventh in the list of states that benefited most from the Soviet aid by getting economic aid (Özkoc, 2008: 143).

As soon as Hafez Assad came to power, he worked with a strategy of continuing the alliance with the Soviet Union and strengthening relations. Considering the reasons why Hafez al-Assad adopted this strategy, first of all, the idea of protecting Syria's national interests and his power. Other issues can be listed as follows:, The absence of an alternative power to the Soviet Union, the establishment of the military and economic structure of Syria according to the Soviet model, the intelligence support from the Soviet Union, the ideology of the Soviet ideology and the overlapping ideological base of the Assad administration and the aid from Soviet administration.

The two main reasons of the Soviet Union's support for Syria at that time can be summarized as follows (Karabulut, 2007: 74): First of all, to provide the Western bloc's loss of position in the Middle East by spreading the discourse of Syria, which has an anti-imperialist and anti-militant attitude. The second was to ensure that the Soviet Union had one leg in the Eastern Mediterranean in order to protect the nuclear balance. Otherwise, the United States would have been able to disrupt this balance with its nuclear missiles placed in submarines patrolling the Eastern Mediterranean. In this period, when the Soviet influence on Syria is examined in more detail, it is seen that the relations are concentrated more in the military field. For example, the Soviet Union, military experts in Syria, as well as an epicenter of the sea from Tartus; the other epicenter has protected Syrian territory from air, including Tiyas. 


\section{Russia-Syria Relations in The post-Cold War Era}

Right after the end of the Cold War, the Russian Federation got stuck with a number of political, social and economic problems led by the hard transition period in the 1990 s and started to withdraw from some of the formerly active regions. Syria, on the one hand, while trying to adapt to the post-Cold War period, the other side of the effort not to lose its closest ally. The relations of the two countries, which were almost frozen due to Syria's debts from the Soviet Union during 1990s, began to make the relations softer in July 1999 after the visit of Hafiz Assad in Moscow. According to Izvestiya newspaper, there are three main causes why the Russian Federation wants to once again revive its relations with Syria (Çalışkan, 2016). The first one is that Moscow, which is demanding an ambitious role in the Middle East, wants to be a mediator in the Middle East peace process and therefore needs the Syrian front. Other considerations are the importance of the Port of Tartus in terms of Russia's presence in the Mediterranean area and the contribution of Syria to the modernization of the the former Soviet weapons.

With Putin coming to the presidency in Russia, a new era has begun in Russian domestic and foreign policy (Tellal, 2010: 227-228). For Putin, the most important concepts of international politics are realism and pragmatism (Kreutz, 2007: 25). Therefore, he tried to approach his relationship with Syria from this perspective. During Putin's first years of office, Russia faced two major problems; economic crisis and Chechen resistance. In order to tackle these two problems, good relations with the West were needed. Under all these conditions, Putin, in the first five years of his presidency, tried to lift the Russian economy with the investments he made from the West as well as the oil and natural gas pipelines. Russian interest in Syria has followed a much more limited course since he did not want any deterioration in relations with the US and Israel during this period.

Bashar al-Assad made a state visit to Moscow in January 2005 and six agreements were signed to strengthen the bilateral relations between the two sides. In this visit, the deletion of $73 \%$ of Syria's debts from the Soviet Union's time in return for new arms agreements has accelerated the development of the relations between the two countries. Once this agreement was reached with Syria, many Russian strategists began to discuss the need to expand Port of Tartus and move the Black Sea Fleet into the region in the event of a problem by Ukraine. The alleged connection to Syria behind the assassination of Lebanese Prime Minister Refik Hariri in February of the same year left Damascus administration facing international pressure. However, Russia rejected the international pressure by opposing the embargo against Syria in the UN. Once again, international challenges have brought the two countries closer together.

\section{Importance of Syria (2005-2011)}

On 25 January 2005, Bashar Assad's first visit to Moscow was a major turning point in Russia's Syria policy. During this visit Syria became a major problem in the bilateral relations in the post-Cold War period. and the remaining 3 billion 600 million dollars in installments. In addition to this, despite the objections of the United States and Israel Moscow has accepted the sale of Syria's long-awaited advanced air defense systems. According to the Russian newspaper Kommersant this deal, which was over $\$ 100$ million, was completed in the same year as the order of Putin. It was also understood that the technical maintenance station in the Tartus Port of Syria, which is connected to the Black Sea Fleet of Russia, was turned into a full naval base (Katz, 2006: 55-56).

In a sense the geopolitical concerns that Russia felt in its immediate vicinity increased the importance of Syria for the Kremlin. Moscow, which began to think of Syria as a strategic area where it could establish events outside its own environment, as it was during the Soviet Union period, tried to develop a strategy at this point from 2005 on.

In April 2005 economic ministers of the two countries came together and signed a protocol to improve cooperation in areas such as banking, industry, oil, transportation, health, tourism, communication, higher education, irrigation, agriculture and investment. Amir Lutfi the Syrian Minister of Economy of the period announced that the Syrian government is ready to take all measures to increase Russian investment in tourism construction of large industrial sites oil and gas extraction. It was also decided to increase the number of Syrians studying in Russian military academies (Aslanll, 20018). In a sense the relative stasis in the relations between Russia and Syria in the post-Cold War period has begun to disappear in this process. 
The most important developments that gave impetus to Russia's Syria policy were experienced in defense. Moscow sold air defense systems in April 2005, but rejected the sale of strategic systems such as Alexander and Igla, which Damascus had requested many times after the intense objection of Israel. Russia wanted to sell more weapons to Syria in this process, but did not want to disrupt its trade with Israel. As a matter of fact, in spite of the protests that started in Russia and the USA after the sale of weapons to Russia both Putin and Russian Foreign Minister Sergei Lavrov said that the weapons had defensive systems and did not contain any strategic weapons that would undermine the balance in the Middle East (Kreutz, 2007: 15). The developments are a sign that Russia is trying to be an effective actor in the Middle East.

Russia, which continued to improve its relations with Syria, aimed to counter NATO's enlargement, particularly by strengthening its military presence in the Mediterranean (Kiraz, 2016: 304-305). At this point the geopolitical concerns of the stronger Russia have led to a more active attitude in Syria policy.

\section{Syria Policy of Russia}

Russia after a short period of liberal and Western foreign policy after the dissolution of the Soviet Union tried to pursue a more pragmatic foreign policy, especially when Vladimir Putin came to power (Tsygankov, To, 2012: 129-134). When Vladimir Putin became President of Russia, a new era has started in Russian domestic and foreign policy. The foreign policy perception document, published on June 28, 2000, has guided Putin's foreign policy with its multi-polarity and active foreign policy objective. For Putin, realism and pragmatism are the most important concepts of international politics (Mikail, 2007: 70-78). It was argued that Putin emphasized Syria in terms of a strategy of return to the old days (Aghayev, Katman, 2012: 11).

In the period of Vladimir Putin, Russia's Syria policy was examined in four periods. The process until 2005 when Putin was engaged in domestic problems more than in 1999 when he was Prime Minister was considered as the first period. The period from 2005 to 2011 (the beginning of the Arab Rebellions) was stated as the second period. The process from 2011 to 2014 is depicted as the period in which Syria relocated to Russian foreign policy. The process that started with Russia sending troops to Syria in 2015 was written as the fourth period.

In order to understand today's Russian Federation's foreign policy in the outbreak of the Syrian civil war, a good understanding of the historical background of the global two forces is necessary. Russia is in competition with the United States (US), the European Union and the regional powers in the international political system. The Russian Federation has implemented its foreign policy on protecting the Russian interests in Syria. Russia took part in Bashar al-Assad in the Syrian civil war. The "Arab Spring", which emerged in the Arab countries in 2010, revealed important political results in Middle Eastern politics.

It is not possible to understand the international politics, war, economy, diplomacy and strategy in the Arab Spring without understanding the Russian Federation's historical interest and policy in the Middle East and Syria. Russian Federation's quiet and deeply moving diplomacy capability towards the Middle East and its historical background will make it easier for us to understand Russia's policy towards the Middle East and Syria. Russia remained the most influential state at the beginning of the regime, providing political support to Syria. Russia's choice to stand in the current Syrian regime is very interesting and offers an important opportunity to identify some motivating factors that have led Russia to stand up in the Assad-led regime. Both countries have common interests in their international relations. These interests include economic and social interests, military interests and strategic considerations. The next chapters will discuss the Syrian-Russian relationship in more detailed way.

In conclusion, it is argued that the Russian Federation showed the US and NATO that it is a global and regional power with the Syrian civil war intervention. Russia's intervention in the Middle East with Syria's foreign policy has affected the balance in the region. Russia used diplomacy in Syria as well as military power and especially vetoed the resolutions of Syria in the United Nations Security Council. At the national level, Russia's interests and reasons of veto in Syria can be summarized as follows. Russia's only gate to the Mediterranean Sea is the Tartus Naval Base. The only way out of Russia's energy relations with Iraq is to be a military base. Also, considering the oil and natural gas reserves under the Eastern Mediterranean, Russia's presence in the Mediterranean which has largely turned its energy over the energy, seems to be 
linked to the Tartus Naval Base. Furthermore, having an ally in such a valuable region can prevent the exclusion of Russia in the new energy equation (Sağlam, 2014).

\section{The Arab Spring and Syria}

Arab Spring refers to the sum of revolutions in North African countries and Middle Eastern region. The reason why these revolutions are seen as Arab Spring is the revolt of the people against dictatorial regimes that have been going on for several centuries. On the basis of these uprisings, there are dictatorial rules, as well as unemployment, food inflation, political corruption, economic crisis, lack of liberties like the freedom of expression and poor living conditions. In other words, it is the sum of popular movements in Middle East countries, which are the protests, uprisings, revolutions, revolts and many more.

In 2011, large scale peaceful demonstrations demanding political and economic reforms in Syria have turned into a complete civil war that has become one of the major problems on the international agenda. The chief offender of the onset of violence is the authoritarian regime of Syria and it resort to violent pressures and measures to suppress rebellions. According to the reports issued by UN, the Syrian regime was dealing with systematic human rights violations and the lack of rights of food and health, excessive use of force against protesters, arbitrary detentions, summary executions, abductions, enforced disappearances and torture etc. These reports have no doubt that some of the actions of the regime constitute a crime against humanity.

While some countries went beyond by providing support for the insurgents, the responses of the international society at large have not been enough to force the Syrian regime to change its leadership to step down. While a number of factors contributed to this development, the most important was the position adopted by Russia. Trusting the support given by China, Russia has actively resisted most steps to hike up international pressure on the regime at the United Nations through blocking no less than three Security Council resolutions on Syria, thereby preventing sanctions and depriving of legitimacy of any considerations for humanitarian intervention. (Johanne, Allagui, 2011).

While there were no intense conflicts and violence outside of Libya, the Syrian uprising had completely changed the regional balances and was the beginning of a much longer period in contrast to expectations. Syria has experienced a process involving surprising elements and articulations in its internal balances. The involvement of external actors and the active role of these actors in the Syrian policies have played a leading role in the process. Although the demonstrations in Syria quickly expanded, it did not grow as soon as in Egypt and Tunisia. As in the case of Bahrain, the Syrian uprising became a violent civil war in a sectarian relationship and there was no social peace (International Crisis Group, 2016: 1).

In the face of demonstrations across Syria, the Assad regime lost control and resorted to harsh military measures. In this process, the legitimacy of power entered into crisis. The opposition, which was armed against the regime, increased its social support by entering violent clashes with the regime forces. In this process, Assad began to lose his army and completely lost his support outside of a limited sector. The opposition, despite its fragmented structures, has progressively reduced the control of the regime in the country. Iran was one of the most important supporters of the Assad regime since the early years of the civil war. Provides military support to the regime by providing human support in the field. But despite this support, the regime lost control across the country and was stuck in small areas. This merciless regime began to kill innocent civilians in the name of combating terrorism using all kinds of weapons, including chemical weapons. Although international forces condemned the use of chemical weapons in particular, they did not resort to any measures. The Assad regime continued to recklessly use chemical weapons without hesitation. Actors such as the United States and Turkey were urged to pave the way for the democratic process and stop the attacks in this situation. But nothing changed (El Sarraj ve Taşgin, 2016: 4).

Considering what Russia has done in this process; Russia intervened in response to the US response and proposed the dissolution of Syria's stock of chemical weapons. Especially Russia was a very important role in this process. Because Russia changed the balance in the civil war. The intervention of Russia enabled the regime forces in the field to hold on to the field. Thanks to this comfort, the Assad regime developed complex relations with other actors of the civil war, PYD and DEASH, in order to maintain its existence. 


\section{How did Russia Adopt a Military-Political Strategy?}

One of the motivations behind Russia's policies in Syria is to exist and strengthen in the Middle Eastern region and the Mediterranean region. With this, Russia gains an advantage in restoring its global power position, increases its security capacity, and is strong in the global energy game (the capacity of Syria as a potential energy source and energy route). Putin's definition of Syria as a central country in terms of Middle East policy is also important in this context. The importance of the Middle East in 3 different places $(15,16$ and 18 ) in the National Security Strategy of the Russian Federation, which was approved by Putin on 31 December 2015, and noted that Russia will continue to claim Russia as the world's leading power has been mentioned. However in the National Security Strategy of the Russian Federation on 12 May 2009 (officially the National Security Strategy of the Russian Federation-up to 2020), the Middle East was only mentioned in Article 11. From time to time, it is claimed that Russia and its main purpose is to protect the interests of the Assad regime not the Assad regime but also the interests of the Eastern Mediterranean, and therefore it tries to protect not only Damascus and its environs but also Latakia and Tartus (Aslanlı, 2018).

\section{Conclusion}

The Russian Federation still plays an important role in the Syrian crisis, one of the most critical problems of the international arena. Therefore, the role of this country in the context of the Syrian crisis is among the subjects that require the most research. There are many reasons for Russia to stand steadily behind Syria at all costs. In order to understand Russia's policy in the Syrian crisis, it was necessary to touch upon the special relationship between Russia and Syria. Because the relationship between the two countries have not only financial issues but also political and strategic importance.

After the spread of the Arab uprisings to Syria, Russia became one of the global actors of the problem. Russia, under Putin's leadership, has begun to pursue a more ambitious and decisive policy than any other country in the Middle East and even beyond its immediate vicinity. This raised questions about Russia's policy towards the region. However, not so long ago, in the Cold War years, the Russians followed the most effective policy in the Middle East and even their global rivals had many successes against the US. Similar to the Cold War period, Russia's political, military and economic presence in Syria proves that it can exist in a region outside its own environment. Although Russia is not a regional country, it is trying to make itself felt in the first league among international actors and to feel its weight in regional and global issues. The main reason Russia can do this is undoubtedly due to its veto power in United Nations Security Council (UNSC).

Russia continues to support the Assad regime in the light of the reasons stated in this study. However, this policy is also a policy with some handicaps for itself. No power in the world that fights with its own people has been successful until now. The repressive regimes trying to bring their people to the forefront through violence have become history. In the civil war of Syria, Assad expects a similar fate. However, as Russia can not escape from its old behaviour patterns, it progresses gradually in Syria to failure. Each situation can be written to the loss point for Russia. The Assad regime is more marginalized and excluded due to increasing dose of violence. It is now a matter of time for Assad to move away from power even when its time is unpredictable. According to optimistic scenarios, perhaps the regime could be buried in history with Assad and a new Syria could be established. If the Assad regime collapses, the newly established regime will review its relations with Russia, which supports the old regime. If the Assad regime is not destroyed, Russia will have a negative image as it will be seen as the only supporter of such a bloody regime.

The crisis and the conflict in Syria is still in progress in 2019, and it does not seem to come to an end. When one looks at the current process, it can be seen that the administration of Bashar Assad will not leave the country administration today and in the near future. Syria has officially turned into a field of political reckoning Consequently, it is necessary to see Russia's Syria policy not only as a policy towards the Middle East, but also as a struggle for hegemony against the West, which was led by the United States since 2008. 


\section{References}

Aghayev, 2012 - Aghayev, E. ve Katman, F. (2012). Historical background and the present state of the Russian-Syrian relations. European Researcher, Vol. 35, No 11-3, pp. 2066-2070.

Aslanll, 2018 - Aslanl, A. (2018). Rusyanın Suriye Politikası No: 75 ORSAM.

Çalışkan, 2016 - Çalışkan, B. (2016). Rusya-Suriye İlişkileri ve Ortadoğu Krizlerine Etkisi. İHH İnsani ve Sosyal Araştırmalar Merkezi. [Electronic resourse]. URL: http://www.ihh akademi.com/wp-content/uploads/2016/o3/Rusya-Suriye-Ilisskileri-ve-Ortadoğu-KrizlerineEtkisi.pdf

El Sarraj, 2015 - El Sarraj, A. ve Taşgın, C. (2015). Arap Baharı ve Suriye İç Çatışması. İstanbul: Fikir Enstitüsü Yayınları.

International Crisis Group, 2019 - International Crisis Group (2019). The Best of Bad Options for Syria's Idlib, Report no 97. [Electronic resourse]. URL: https://www.crisisgroup.org/ middle-east-north-africa/eastern-mediterranean/syria/197-best-bad-options-syrias-idlib ICTs.

Johanne, Allagui, 2011 - Johanne, K., Allagui, $\dot{I}$. (2011). The Arab Spring and the Role of

Karabulut, 2007 - Karabulut, B. (2007). Karadeniz'den Ortadoğu’ya uzanan bir dis, politika: Geçmișten günümüze Rusya Suriye ilișkileri. Karadeniz Araşttrmaları, Sayı 15, pp. 69-91.

Katz, 2006 - Katz, M.N. (2006). Putin's Foreign Policy Toward Syria. Middle East Review of International Affairs, Cilt 10, Sayl 1, pp. 53-62.

Kiraz, 2016 - Kiraz, S. (2016). Bağımsızlıktan 21. Yüzylla Suriye-Rusya Siyasi Ilisşkileri.

Mehmet Akif Okur ve Nuri Salık (Ed.), Bağımsızlıktan Arap Baharı'na Suriye: Ic, ve Dıs, Politika içinde. Ankara: Nobel Yayınevi.

Kreutz, 2007a - Kreutz, A. (2007). Russia in the Middle East: Friend and Foe? London: Praeger Security International.

Kreutz, 2007b - Kreutz, A. (2007). Russia in the Middle East: Friend and Foe? London: Praeger Security International.

Özkoç, 2008 - Özkoç, Ö. (2008). Suriye BAAS Partisi: Kökenleri, Dönüşümü, Izlediği Ic, ve Dıs, Politika (1943-1991). Ankara: Mülkiyeliler Birliği Yayınları.

Sağlam, 2014 - Sağlam, M. (2014). Inadın Ötesinde: Rusya'nın Suriye Politikası. Ankara Üniversitesi SBF Dergisi, 68 (4): 211-217.

Tellal, 2010 - Tellal, E. (2010). Zümrüdüanka: Rusya Federasyonu'nun Dış Politiksı. SBF Dergisi, 65 (3): 189-236. 